\title{
SEEING PENNSYLVANIA AS THE KEYSTONE OF THE REVOLUTION: CHARLES H. LINCOLN'S TREATMENT OF ETHNICITY
}

By Greg Rogers

Charles H. Lincoln's 1901 The Revolutionary Movement in Pennsylvania 1760-1776 is an insightful examination of the internal politics of a state often overshadowed by Massachusetts and Virginia in studies on the roots of the American Revolution. In addition to being a valuable secondary source, Lincoln's monograph can also be read as a primary source, specifically with regard to the issue of ethnicity. Lincoln's argument relies heavily upon a particular conception of ethnicity, wherein ethnic identity, shaped by shared past experiences, influences the actions and interests of historical actors. This formulation of ethnicity and its importance can be attributed, in part, to the monograph's focus on Pennsylvania, the most culturally heterogeneous of Britain's North American colonies. However, the influence of progressive historiography, and the Progressive Era in general, distinctly shape both Lincoln's focus and his thesis regarding the origins of the Revolution. The concept of ethnicity, as fashioned by the author's social and intellectual surroundings, greatly affected Lincoln's analysis of 
Pennsylvania's internal conflicts and their connection to the American Revolution as a whole.

Lincoln's study begins with a thorough analysis of the roots of Pennsylvania's "internal” revolutionary movement by highlighting the ethnic, sectional, religious, and geographic differences that led to a fissure between the ruling Quaker elite and the marginalized immigrants, urban workers, and western settlers that were growing in size and influence. Following this, Lincoln examines the consolidation of political factions into parties, which culminated in the demise of Quaker hegemony in Pennsylvania in the elections of 1775 and 1776, thus replacing the old order while simultaneously endorsing "the assertion of national independence." The presence of such interrelated contests is the foundation of the so-called "dual-revolution thesis," in which revolution was directed against both an external agent (Britain) and against forces within the colony itself. This thesis was a key component of Progressive Era historiography. Lincoln's articulation of this thesis predates the better-known, but arguably weaker, version made by Carl Becker in The History of Political Parties in the Province of New York, 1760-1776, and is distinguished from Becker's account-and the general body of Progressive-Era literature on the Revolution-in its treatment of ethnicity. In Lincoln's work, the role of different ethnic groups and their grievances is a key component to understanding the internal revolt. $^{2}$

In The Revolutionary Movement in Pennsylvania, these ethnic groups are treated as distinct political blocs. For Lincoln, ethnic identity serves as a determining factor for both economic interest and political culture. Given the centrality of ethnicity to his study, it is vital to have an understanding of what he means by invoking the term "race." For Lincoln, ethnic groups are shaped not by their biology or by some "instilled ethnic spirit," but are instead the product of their unique historical experience in the Old and New World.

${ }^{1}$ Charles H. Lincoln, The Revolutionary Movement in Pennsylvania 1760-1777 (Philadelphia: University of Pennsylvania Press, 1901), 234.

${ }^{2}$ Robert Gough, "Charles H. Lincoln, Carl Becker, and the Origins of the DualRevolution Thesis," William and Mary Quarterly 38, no. 1 (Jan. 1981): 97-98. 
Lincoln addresses three major political blocs: the Germans, the Scotch-Irish, and the English Quakers. In Lincoln's work, the Germans are endowed with a political culture characterized by an overriding distrust for all government, be it imperial, colonial, or local. These misgivings were based upon their past experience in various German states, England, colonial New York, and, eventually, in Pennsylvania itself-experiences that were retained in ethnic memory. Furthermore, they display no affinity or ties to traditional English political ideas. As a result, they prefer to be left alone and typically serve as a passive ally to either the Quakers or Scotch-Irish when they engage in politics. As revolutionary thought and action took center stage, however, Lincoln argues that the "race as a whole" embraced the cause of independence because they lacked "ties of blood" to England and were offered political equality. ${ }^{3}$

Like the Germans, the Scotch-Irish are also treated as a dissenting ethnic community. According to Lincoln, two centuries of experience with the English and the settlement of Ireland gave rise to a serious interest in politics, a "fierce" desire to protect their rights, and "confidence in the principles of democracy." ${ }^{\prime 4}$ Additionally, their history with the Gaelic Irish was viewed as influential in their dealings with Native American populations in Pennsylvania's western frontier, providing the basis for their assertion that the land was theirs to settle by the laws of God. The Scotch-Irish that had settled Ulster County, Ireland throughout the seventeenth and eighteenth centuries cared little for the Catholic Irish that they were expropriating land from and viewed them as backward savages. Native Americans thus played a role similar to that of the Gaelic Irish as the Scotch-Irish transplanted their religious justification for settlement across the Atlantic. It is in the Scotch-Irish that Lincoln locates the "spirit of colonial resistance to England."5

The English Quakers are the last group dealt with in detail by Lincoln. In short, Lincoln contends that, despite their minority religious affiliation, the Quakers were representative of the British ruling

\footnotetext{
${ }^{3}$ Lincoln, 24-27, 31-32, 36.

${ }^{4}$ Ibid., 32.

${ }^{5}$ Ibid., 32-36.
} 
classes that the American Revolution ultimately sought to overthrow. Therefore, the Quakers were a stark English foil to the aforementioned ethnic groups.

In addition to dealing with ethnic groups as distinct units, Lincoln's concern with ethnicity also results in an interest in immigration. The explosion of German and Scotch-Irish immigration after the second decade of the eighteenth century is depicted in a political context. Having arrived first and established the structure of the colonial government, the Quakers understandably were concerned about changing demographic trends. Lincoln sees the emerging power struggle as a game of numbers-one in which the ruling elite were forced to watch their own population become eclipsed by the influx of new immigrants. In the face of this irreversible trend, the Quakers sought to maintain political control, and did so until the mid-1770s. The relationship between immigration and control over the colony politicized the issue of immigration so that it became a point of contention between the later proprietors and the colonial legislature. While William Penn was wary of an "open door" policy, later proprietors, motivated by economic gains from land sales, had much fewer qualms about inviting a wide variety of immigrants into the colony. ${ }^{6}$

Although Lincoln placed a great deal of emphasis on ethnic identity, it was not necessarily the supreme factor in his study. Economic interests, religion, regionalism, and class differences were also present in his analysis. Nevertheless, Lincoln often connected these other factors to issues of ethnicity. For instance, he argues that the concerns of the frontier were not wholly shaped by geography and security, but were also influenced by the fact that those living in the frontier region were overwhelmingly German and Scotch-Irish-a consequence of the fact that the Quakers had intentionally encouraged the settlement of these groups away from Philadelphia in order to marginalize their influence and provide a buffer against the occasionally hostile Native American tribes. ${ }^{7}$ Lincoln also connects ethnicity to economic concerns. For instance, Lincoln argues that German and Scotch-Irish affinity for the

\footnotetext{
${ }^{6}$ Ibid., 33-36, 80.

${ }^{7}$ Ibid., 34 .
} 
colony of Maryland and its center of trade in Baltimore can be credited to the similar ethnic heritage between residents of Maryland the new immigrants to the north. Sharing a similar ethnic background, these groups became "racially united," resulting in close trading ties. This shift in economic and even political allegiance contributed to the friction between Philadelphia and its outlying communities. ${ }^{8}$

There are three primary factors that can shed light on Lincoln's perspective on ethnicity: (1) his focus on Pennsylvania, (2) trends within Progressive scholarship, and (3) the influence of the Progressive Era in general. Any scholar with at least a passing interest in the American Revolution and colonial America cannot help but notice the striking ethnic diversity within Pennsylvania during the eighteenth century. More than any of the other thirteen colonies, Pennsylvania was characterized by ethnic pluralism. By 1750, the English Quakers accounted for only one-third of the population-a number roughly equal to the number of Scotch-Irish in Pennsylvania. The German segment had grown to constitute about 40 percent of the total. In addition, there were small but visible communities of Welsh, Swedish, Dutch, and Scottish colonists. Since the English were least numerous in the middle colonies, particularly in Pennsylvania, these areas were most ripe for ethnic studies. ${ }^{9}$ Pennsylvania also lends itself to the type of ethnicpolitical blocs put forward by Lincoln because of the nature of its political contests. While familial groups or loosely defined factions dominated other colonies, Pennsylvania had perhaps the clearest instance of party politics. This structure, paired with the existence of a clearly English elite and a non-English periphery, are the essential components that underlie Lincoln's advancement of the dualrevolution thesis. ${ }^{10}$

Beyond the particularities of his subject matter, developing trends among Progressive Era historians also influenced Lincoln's handling of ethnicity. Over the course of the nineteenth century, historians began

${ }^{8}$ Ibid., 55, 75-76.

9 Alan Taylor, American Colonies: The Settling of North America (New York: Penguin, 2001), 271-272, 321.

${ }^{10}$ Alan W. Tully, "Ethnicity, Religion, and Politics in Early America," The Pennsylvania Magazine of History and Biography 107, no. 4 (Oct. 1983): 493-494. 
to expand their conception of who constituted the American people. No longer limited to Protestant Anglo-Americans, the works of scholars like Frederick Jackson Turner and Charles Beard began to draw attention to other ethnic groups. While this movement did not fully materialize until after the First World War, Lincoln and his contemporaries, writing in the late 1800 s and early 1900 s, can be seen as its forerunners. ${ }^{11}$ This is evidenced in his sources for the chapter "The Influence of German and Irish Immigration." He utilizes a plethora of works, almost all written in the 1890s, that are ethnic histories of the two groups in question. This is a strong testament to the vitality of ethnic studies in the early progressive period. ${ }^{12}$

This shift in historical interest was at least partially influenced by contemporary events taking place during the progressive era. Between 1890 and 1893 alone, there was an annual influx of about half a million immigrants. This new wave of immigration consisted primarily of Slavs, Italians, Russians, and Jews-groups that were culturally and politically quite different from the "old immigrants" of a century before. These differences caused a vocal and powerful backlash of nativism. ${ }^{13}$ Whether or not progressive historians were concerned with colonial immigration and ethnicity because of their nativist leanings or because of their hopes for the infusion of new diversity is an area that remains to be explored. Regardless, ethnicity and immigration were certainly salient issues of the time. Lincoln's discussions of the debates surrounding the Pennsylvania colony's immigration policy clearly parallel those taking place in the United States Congress. Questions concerning an open door policy versus a more restrictive approach were not just the milieu of the past-they were also present in Lincoln's world. Philadelphia, the city where he worked on his $\mathrm{PhD}$ and published The Revolutionary Movement, was a minor port of entry for immigrants and, more importantly, "an immigrant city." Between the years of 1900 and 1920 the population of those coming from ethnic

${ }^{11}$ John Higham, History: Professional Scholarship in America (Baltimore: Johns Hopkins University Press, 1989), 191-192.

${ }^{12}$ Lincoln, 23.

${ }^{13}$ Faith Jaycox, The Progressive Era, (New York: Facts on File, 2005), 7, 30-31. 
groups considered being 'new' immigrants nearly quadrupled from at least 60,000 to well over 200,000. ${ }^{14}$ The Pennsylvania of 1901 was clearly involved in an ethnic influx with political and demographic consequences not dissimilar to those of the Pennsylvania of 1750 .

To some degree, all works of history are a product of their author's environment. A historian's surroundings shape and direct an analysis just as much as his or her theoretical inclinations. Written in another time, or about another place, Lincoln's The Revolutionary Movement in Pennsylvania would have been a significantly different work. His distinct view and emphasis on ethnicity and the related issue of immigration not only shape of his thematic content but also his argument. The colony is presented as a model of the British Empire in "miniature." It is a heterogeneous collection of religions, regions, economic interests, and ethnicities or "races." It is ethnicity, constructed by Lincoln as political-economic blocs, that usually transcends these other concerns. Far from being an obstacle, this diversity actually strengthened democracy as different groups had to unite and cooperate in order to overthrow ruling elites, Quaker or imperial. "Disunity" was an "excellent foundation for revolt." 15 Whether or not Pennsylvania and Progressive Era thinking present a skewed and inaccurate account of the American Revolution is open to debate. What is certain is that factors of contemporary time and provincial place are just as evident in Lincoln's text as the broader thesis he pioneered.

${ }^{14}$ Frederic M. Miller, "Immigration Through the Port of Philadelphia," in Forgotten Doors: The Other Ports of Entry to the United States, ed. M. Mark Stolarik (Philadelphia: Balch Institute Press, 1988), 37, 48.

${ }^{15}$ Lincoln, 3,13, 53-54, 114, 189. 


\section{BIBLIOGRAPHY}

Gough, Robert. "Charles H. Lincoln, Carl Becker, and the Origins of the DualRevolution Thesis." William and Mary Quarterly 38, no. 1 (Jan. 1981): 97-109.

Higham, John. History: Professional Scholarship in America. Baltimore: Johns Hopkins University Press, 1989.

Jaycox, Faith. The Progressive Era. New York: Facts on File, 2005.

Lincoln, Charles H. The Revolutionary Movement in Pennsylvania 1760-1777. Philadelphia: University of Pennsylvania Press, 1901.

Miller, Frederic M. "Immigration Through the Port of Philadelphia." In Forgotten Doors: The Other Ports of Entry to the United States, edited by M. Mark Stolarik, 37-54. Philadelphia: Balch Institute Press, 1988.

Taylor, Alan. American Colonies: The Settling of North America. New York: Penguin, 2001.

Tully, Alan W. "Ethnicity, Religion, and Politics in Early America." The Pennsylvania Magazine of History and Biography 107, No. 4 (Oct. 1983): 491-536. 